\title{
Effect of Cultivar, Irrigation and Nitrogen Fertilization on Chickpea (Cicer arietinum L.) Productivity
}

\author{
Kico Dhima1 ${ }^{*}$, Ioannis Vasilakoglou' ${ }^{2}$, Stefanos Stefanou ${ }^{1}$, Ilias Eleftherohorinos ${ }^{3}$ \\ ${ }^{1}$ Department of Agricultural Technology, Technological Educational Institute of Thessaloniki, Thessaloniki, \\ Greece \\ ${ }^{2}$ Department of Agricultural Technology, Technological Educational Institute of Thessaly, Larissa, Greece \\ ${ }^{3}$ School of Agriculture, Faculty of Agriculture, Forestry and Natural Environment, Aristotle University of \\ Thessaloniki, Thessaloniki, Greece \\ Email: ${ }^{\text {dimas@cp.teithe.gr }}$
}

Received 4 September 2015; accepted 18 October 2015; published 22 October 2015

Copyright (C) 2015 by authors and Scientific Research Publishing Inc.

This work is licensed under the Creative Commons Attribution International License (CC BY).

http://creativecommons.org/licenses/by/4.0/

(c) (i) Open Access

\section{Abstract}

A 2-year field study was conducted in northern Greece to investigate the effect of nitrogen fertilization and irrigation on productivity of three Greek chickpea varieties ("Amorgos" "Serifos", "Andros"). Chickpea, grown under irrigation regime (30 + $30 \mathrm{~mm}$ of water) and fertilized with 50 $\mathrm{kg} \cdot \mathrm{N} \cdot \mathrm{ha}^{-1}$ before planting and with $40 \mathrm{~kg} \cdot \mathrm{N} \cdot \mathrm{ha}^{-1}$ at blossom growth stage, produced more total dry biomass and seed yield as compared with that grown under non-irrigated conditions and fertilized with $50 \mathrm{~kg} \cdot \mathrm{N} \cdot \mathrm{ha}^{-1}$ before planting only. In particular, irrigation and nitrogen fertilization at blossom growth stage increased total dry weight of chickpea by $18.3 \%$ and $18.5 \%$, respectively, as compared with that of non-irrigated and fertilized with $\mathbf{N}$ before planting. The corresponding increase of seed yield was $\mathbf{3 0 . 5 \%}$ and $\mathbf{2 0 \%}$, respectively. The total dry biomass of "Amorgos" was $10 \%$ and $13 \%$ greater than that of "Serifos" and "Andros", while its respective seed yield increase was $5 \%$ and $16 \%$. Finally, the quantum yield of photosystem II of chickpea was not affected by irrigation or fertilization. These results indicated that nitrogen fertilization at blossom growth stage combined with irrigation increased seed yield of all chickpea varieties, whereas the same treatments did not have any effect on plant quantum yield of photosystem II.

\section{Keywords}

Chickpea (Cicer arietinum L.), Irrigation, Nitrogen Fertilization, Dry Biomass, Seed Yield, Quantum Yield of Photosystem II

\footnotetext{
${ }^{*}$ Corresponding author.
}

How to cite this paper: Dhima, K., Vasilakoglou, I., Stefanou, S. and Eleftherohorinos, I. (2015) Effect of Cultivar, Irrigation and Nitrogen Fertilization on Chickpea (Cicer arietinum L.) Productivity. Agricultural Sciences, 6, 1187-1194. 


\section{Introduction}

Chickpea (Cicer arietinum L.) is one of the most important grain legumes as it ranks third in the world after dry bean (Phaseolus vulgaris L.) and field pea (Pisum sativum L.) [1]. Its good source for protein, complex carbohydrates, fibre, vitamins and minerals [2] [3] makes this legume an important component of human diet in developing world [4] [5]. Generally, its protein quality is higher than that of many other legumes [6].

Chickpea is a significant contributor to agricultural sustainability due to its nitrogen fixation ability and for this reason is considered a good rotational crop [1]. Its presence improves soil health by promoting microbial population and activity [7] [8]. Although chickpea fixes nitrogen from atmosphere, there is strong evidence that nitrogen fertilization increases seed yield, seed protein and amino acids [9]-[12]. However, its requirements for nitrogen fertilization are lower than other crops to obtain higher yield and improved seed quality [13].

Chickpea is grown on a wide range of environments, from the subtropics (India and North-eastern Australia) to arid and semi-arid environments of Mediterranean climatic regions (Mediterranean basin and Southern Australia). Although several researchers [14]-[16] have reported that this crop can grow under environmental stress conditions such as drought, high temperatures and poor soils, Krishnamurthy et al. [17] found that drought stress reduced plant growth and yield by reducing leaf surface area and rate of photosynthesis. In addition, Leport et al. [18] showed that early water stress reduced total biomass and seed yield of chickpea, while Saraf et al. [19] stated that moisture excess or deficit caused significant yield reduction on this crop.

Taking into consideration the partial drought tolerance of chickpea along with its increasing grain legume value in sustainable agricultural systems [20], this crop can play an important role in the traditional semi-arid areas of Mediterranean basin. Furthermore, chickpea may be an important food security crop in the semi-arid and dry environments of northern Greece and it can serve as an important winter rotational crop in this region.

Based on the above findings that indicate the great importance of water and nitrogen availability on the potential growth and yield of chickpea [21], the objective of this research is to assess the effect of nitrogen fertilization at blossom growth stage on productivity of three Greek chickpea varieties (“Amorgos”, "Serifos”, “Andros”) grown under irrigated or non-irrigated conditions.

\section{Materials and Methods}

\subsection{Experimental Sites}

Two chickpea field experiments were conducted in 2007/08 (Year 1) and 2009/10 (Year 2) at the Technological

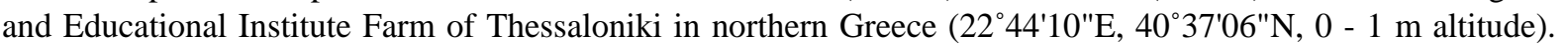
The experiments were established on a sandy loam (Typic Xeropsamment) soil with the following physicochemical characteristics: sand $644 \mathrm{~g} \cdot \mathrm{kg}^{-1}$, silt $280 \mathrm{~g} \cdot \mathrm{kg}^{-1}$, clay $76 \mathrm{~g} \cdot \mathrm{kg}^{-1}$, organic $\mathrm{C}$ content $5 \mathrm{~g} \cdot \mathrm{kg}^{-1}$ and $\mathrm{pH}(1: 2$ $\mathrm{H}_{2} \mathrm{O}$ ): 7.6. Soil analysis ( $0-30 \mathrm{~cm}$ soil depth) conducted before crop planting showed that initial nitrogen content ranged from 86 to 90 and 75 to $83 \mathrm{mg} \cdot \mathrm{kg}^{-1}$ of soil in year 1 and year 2, respectively. The previous crop in year 1 and 2 was wheat and barley, respectively, whereas the mean monthly temperature and total monthly rainfall data recorded near the experimental locations are shown in Figure 1.

\subsection{Treatments and Experimental Design}

Three Greek chickpea varieties (“Amorgos" "Serifos" and “Andros") were planted by hand in 40-cm rows to achieve an approximately desired density of 500,000 plants ha ${ }^{-1}$. The selected chickpea varieties are among the most commonly grown ones in Greece. The planting was performed November 02, 2007 (year 1) and November 14, 2008 (year 2). Two days before crop planting, $50 \mathrm{~kg} \cdot \mathrm{N} \cdot \mathrm{ha}^{-1}$ and $25 \mathrm{~kg} \cdot \mathrm{P} \cdot \mathrm{ha}^{-1}$ as diammonium thiophosphate (20-10-0) were dispersed uniformly and incorporated into the soil of the experimental area. In addition, 40 $\mathrm{kg} \cdot \mathrm{N} \cdot \mathrm{ha}^{-1}$, as ammonium nitrate (33.5-0-0), were applied in half of the plots (namely as fertilized plots) at blossom growth stage. Weed control was achieved by pre-emergence applied pendimethalin at $1.65 \mathrm{~kg} \cdot \mathrm{ai} \cdot \mathrm{ha}^{-1} \mathrm{and}$ by hand weeding.

A split-split-plot arrangement of treatments was employed for both experiments in a randomized complete block design. The three chickpea varieties were arranged as main plots, whereas the irrigation and nitrogen fertilization regimes were arranged as subplot and sub-subplot, respectively. The main plots $(12 \mathrm{~m} \times 3 \mathrm{~m})$ were separated by a $3 \mathrm{~m}$ wide alley. Each main plot was divided into two irrigation subplots $(5 \mathrm{~m} \times 3 \mathrm{~m})$ that were separated by a $2 \mathrm{~m}$ wide alley. Half of the subplots were irrigated two times $(30+30 \mathrm{~mm}$ of water) during the 


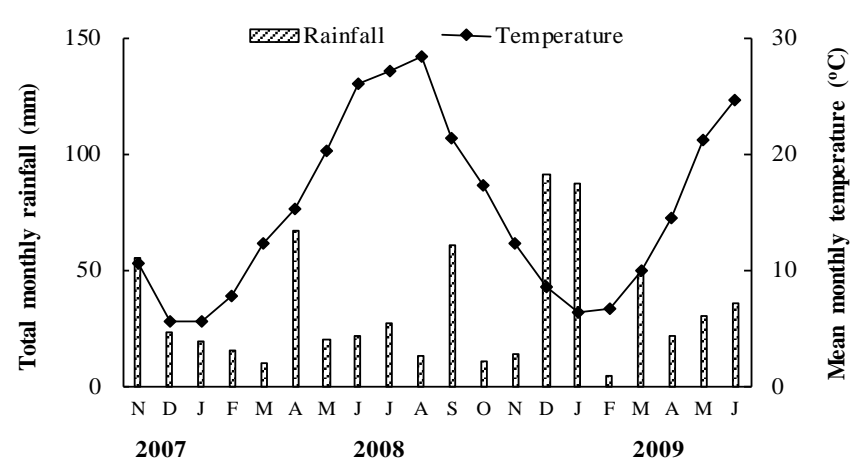

Figure 1. Mean monthly temperature and total monthly rainfall data.

blossom growth stage of crop and the other half was not irrigated. Drip irrigation was performed in rows located $1.5 \mathrm{~m}$ apart. The first irrigation was performed one week before nitrogen fertilization and the other two days later. Each subplot was divided into two $(2 \mathrm{~m} \times 3 \mathrm{~m})$ sub-subplots. Half of the sub-subplots were fertilized with 40 $\mathrm{kg} \cdot \mathrm{N} \cdot \mathrm{ha}^{-1}$ at chickpea blossom growth stage and the other half was not fertilized. Each sub-subplot included five chickpea rows. There were four replicates for each combined treatment (variety $\times$ nitrogen fertilization $\times$ irrigation).

\subsection{Measurements}

Chickpea plants found in the two central rows of each plot were counted at 3 weeks after seeding (WAS). The quantum yield of photosystem II (Y) was also measured at early and late blossom growth stage of chickpea. In particular, the measurements of the chlorophyll fluorescence parameters were made using a chlorophyll fluorometer (MINI-PAM, Miniaturised Pulse-Amplitude-Modulated photosynthesis yield analyzer, Company Walz, Effeltrich, Germany). The measurement of light intensity was of $0.15 \mu \mathrm{mol} \cdot \mathrm{m}^{-2} \cdot \mathrm{s}^{-1}$, with a frequency of $0.6 \mathrm{kHz}$ and a saturation pulse intensity of $16,000 \mu \mathrm{mol} \cdot \mathrm{m}^{-2} \cdot \mathrm{s}^{-1}$ for $0.8 \mathrm{~s}$. Two measurements per plant were made on the upper leaves of five marked plants in the center of each sub-subplot to determine fluorescence at steady-state (Fs) and the maximum fluorescence after saturation flash (Fm). Quantum yield of photosystem II (Y) was calculated using the equation: $\mathrm{Y}=\left(\mathrm{Fm}{ }^{\prime}-\mathrm{Fs}\right) / \mathrm{Fm}$. The average of the ten measurements per sub-subplot was used for further data analysis.

At harvest, total dry biomass, pod number, seed yield (at 14\% seed moisture), and 1000-seed weight of chickpea were determined by hand-harvesting the chickpea plants of the two central rows (each $3 \mathrm{~m}$ long) of each sub-subplot. The plants from each sub-subplot were cut at ground level and, before determination of their total dry biomass and yield components, the samples were air-dried under shade conditions for 3 days and then oven-dried at $65^{\circ} \mathrm{C}$ for $24 \mathrm{~h}$ to constant weight.

\subsection{Statistical Analysis}

A combined across year analysis of variance (ANOVA) was performed for chickpea total dry biomass, pod number, seed yield, and 1000-seed weight data using a split-split plot factorial design (chickpea variety $\times$ irrigation $\times$ nitrogen fertilization). Also, a multivariate analysis of variance (MANOVA) was made for the obtained chickpea quantum yield of photosystem II (Y) data.

The Statistical Package for the Social Sciences [22] and the MSTAT program [23] were used for the MANOVA and ANOVA, respectively, whereas the Tukey's Honestly Significant Difference test procedures were used to detect and separate mean treatment differences at $P=0.05$.

\section{Results}

\subsection{Chickpea Emergence and Physiological Parameters}

Chickpea emergence had been completed within three weeks after planting and the obtained crop density averaged 50 plants $\mathrm{m}^{-2}$ (data not shown), which reflects the desired plant density by the farmers.

Quantum yield of photosystem II (Y), determined at early and late blossom growth stage, did not indicate any 
significant differences due to chickpea varieties, irrigation or nitrogen fertilization (Table 1). However, all chickpea varieties, averaged across irrigation and fertilization regimes, indicated slightly greater yield of photosystem II (Y) at the early blossom growth stage than at the late one (Table 1).

\subsection{Chickpea Total Dry Biomass}

The chickpea total dry biomass indicated significant differences due to nitrogen fertilization $(P<0.05)$ and chickpea varieties $(P<0.05)$. In particular, chickpea (averaged across year, fertilization and varieties), grown in irrigated plots, provided $18 \%$ more total dry biomass than grown in non-irrigated plots, whereas $18.5 \%$ more dry biomass was obtained for chickpea (averaged across year, irrigation and varieties) grown in fertilized plots with $40 \mathrm{~kg} \cdot \mathrm{N} \cdot \mathrm{ha}^{-1}$ applied at blossom growth stage as compared with those grown in non-fertilized plots (fertilized only with $50 \mathrm{~kg} \cdot \mathrm{N} \cdot \mathrm{ha}^{-1}$ before crop planting) (Table 2). Also, "Andros" (averaged across year, irrigation and fertilization) produced 13\% and 3\% less total dry biomass than "Amorgos" and "Serifos", respectively (Table 2).

The three chickpea varieties, grown under any irrigated and fertilization conditions, produced more total dry biomass in year 2 than in year 1 (Table 3). "Amorgos", "Serifos" and "Andros" (averaged across year and fertilization) produced $21.4,20 \%$ and $15 \%$ more dry biomass under irrigation regime than under non-irrigation, whereas their respective total dry biomass (averaged across year and irrigation), grown in fertilized plots, was 20.5, 19\% and 18\% higher than that grown in non-fertilized plots. "Amorgos", "Serifos", “Andros", averaged over years and grown in fertilized plots, produced $20 \%$, $20 \%$ and $13 \%$ more dry biomass, respectively, than in non-fertilized plots, whereas their respective increase in irrigated and fertilized plots was $19 \%, 15 \%$ and $19 \%$ (Table 4). In non-irrigated and fertilized plots, "”Amorgos”, "Serifos” and “Andros” produced 20.5, 22.1\% and $24.1 \%$ more total dry biomass, respectively, than those grown under non-irrigated and non-fertilized plots (Table 3). Finally, in irrigated plots and fertilized plots, their respective increase of total dry biomass was 19\%, $16.3 \%$ and $19.1 \%$.

\subsection{Chickpea Seed Yield}

Pod number $\mathrm{m}^{-2}$ and 1000-seed weight were not significantly affected by variety, irrigation and nitrogen fertilization (data not shown), but seed yield was significantly affected by year $(P<0.001)$, nitrogen fertilization $(P<$ $0.001)$, chickpea variety $(P<0.001)$, and by the interaction between irrigation $\times$ nitrogen fertilization $(P<0.05)$.

Table 1. Quantun yield of photosystem II (Y) as affected by irrigation, nitrogen fertilization and chickpea varieties. Means are averaged across two growing seasons (2007/08 and 2008/ 09).

\begin{tabular}{|c|c|c|c|c|}
\hline \multirow[t]{2}{*}{ Treatments } & \multicolumn{4}{|c|}{$\mathrm{Y}$} \\
\hline & \multicolumn{2}{|c|}{ Early blossom } & \multicolumn{2}{|c|}{ Late blossom } \\
\hline \multicolumn{5}{|l|}{ Irrigation } \\
\hline With & 0.630 & $\mathrm{a}$ & 0.600 & $\mathrm{a}$ \\
\hline Without & 0.625 & $\mathrm{a}$ & 0.611 & a \\
\hline \multicolumn{5}{|l|}{ Nitrogen } \\
\hline $50 \mathrm{~kg} \mathrm{~N}^{1}$ & 0.633 & a & 0.613 & $\mathrm{a}$ \\
\hline $50 \mathrm{~kg} \mathrm{~N}+40 \mathrm{~kg} \mathrm{~N}^{2}$ & 0.622 & a & 0.598 & $\mathrm{a}$ \\
\hline \multicolumn{5}{|l|}{ Variety } \\
\hline Amorgos & 0.627 & $\mathrm{a}$ & 0.609 & $\mathrm{a}$ \\
\hline Serifos & 0.633 & a & 0.601 & $\mathrm{a}$ \\
\hline Andros & 0.623 & a & 0.606 & $\mathrm{a}$ \\
\hline CV\% & \multicolumn{2}{|c|}{7.7} & \multicolumn{2}{|c|}{6.7} \\
\hline
\end{tabular}

Means within each column followed by different letter indicate significant difference; according to Tukey’s Honestly Significant Difference test at $P=0.05$. ${ }^{1}$ Fertilization before crop planting. ${ }^{2}$ Fertilization at blossom growth stage. 
Table 2. Total dry biomass and seed yield of chickpea as affected by irrigation, nitrogen fertilization and variety. Means are averaged across two growing seasons (2007/08 and 2008/ 09).

\begin{tabular}{|c|c|c|c|c|}
\hline \multirow[t]{2}{*}{ Treatments } & \multicolumn{2}{|c|}{ Total dry biomass } & \multicolumn{2}{|c|}{ Seed yield } \\
\hline & \multicolumn{4}{|c|}{$\mathrm{t} \mathrm{ha}^{-1}$} \\
\hline \multicolumn{5}{|l|}{ Irrigation } \\
\hline With & 12.06 & $\mathrm{a}$ & 4.16 & $\mathrm{a}$ \\
\hline Without & 9.85 & $\mathrm{~b}$ & 2.89 & $\mathrm{~b}$ \\
\hline \multicolumn{5}{|l|}{ Nitrogen } \\
\hline $50 \mathrm{~kg} \mathrm{~N}^{1}$ & 12.07 & $\mathrm{a}$ & 3.91 & a \\
\hline $50 \mathrm{~kg} \mathrm{~N}+40 \mathrm{~kg} \mathrm{~N}^{2}$ & 9.84 & $\mathrm{~b}$ & 3.13 & $\mathrm{~b}$ \\
\hline \multicolumn{5}{|l|}{ Variety } \\
\hline Amorgos & 11.84 & $\mathrm{a}$ & 3.79 & a \\
\hline Serifos & 10.69 & $\mathrm{~b}$ & 3.20 & $\mathrm{~b}$ \\
\hline Andros & 10.34 & $\mathrm{~b}$ & 3.58 & a \\
\hline CV\% & \multicolumn{2}{|c|}{16.4} & \multicolumn{2}{|c|}{15.2} \\
\hline
\end{tabular}

Means within each column followed by different letter indicate significant difference; according to Tukey's Honestly Significant Difference test at $P=0.05$. ${ }^{1}$ Fertilization before crop planting. ${ }^{2}$ Fertilization at blossom growth stage.

Table 3. Total dry biomass of three chickpea varieties as affected by irrigation and nitrogen fertilization during 2007/08 (year 1) and 2008/09 (year 2).

\begin{tabular}{|c|c|c|c|c|c|c|c|c|}
\hline \multirow[t]{4}{*}{ Chickpea variety } & \multicolumn{8}{|c|}{ Irrigation (mm) } \\
\hline & \multicolumn{4}{|c|}{0} & \multicolumn{4}{|c|}{60} \\
\hline & \multicolumn{8}{|c|}{ Nitrogen fertilization $\left(\mathrm{kg} \cdot \mathrm{N} \cdot \mathrm{ha}^{-1}\right)$} \\
\hline & \multicolumn{2}{|c|}{$50^{1}$} & \multicolumn{2}{|c|}{$50+40^{2}$} & \multicolumn{2}{|c|}{50} & \multicolumn{2}{|c|}{$50+40$} \\
\hline Year 1 & \multicolumn{8}{|c|}{$\mathrm{t} \mathrm{ha}^{-1}$} \\
\hline Amorgos & 8.55 & cdef & 10.34 & abcdef & 13.36 & abcd & 14.73 & $\mathrm{a}$ \\
\hline Serifos & 7.81 & $\mathrm{f}$ & 8.37 & def & 11.06 & abcdef & 12.28 & abcdef \\
\hline Andros & 7.69 & $\mathrm{f}$ & 8.10 & ef & 10.64 & abcdef & 12.17 & abcdef \\
\hline \multicolumn{9}{|l|}{ Year 2} \\
\hline Amorgos & 10.12 & abcdef & 13.12 & abcd & 10.19 & abcdef & 14.33 & $a b$ \\
\hline Serifos & 8.89 & cdef & 13.06 & abcde & 10.57 & abcdef & 13.52 & abc \\
\hline Andros & 9.87 & abcdef & 12.34 & abcdef & 9.35 & bcdef & 12.53 & abcdef \\
\hline $\mathrm{CV}, \%$ & \multicolumn{8}{|c|}{16.4} \\
\hline
\end{tabular}

Means with different letter indicate significant difference according to Tukey's Honestly Significant Difference test at $P=0.05$. ${ }^{1}$ Fertilization before crop planting. ${ }^{2}$ Fertilization at blossom growth stage.

In particular, chickpea, averaged across year, fertilization and varieties, produced 30.5 more seed yield in irrigated than in non-irrigated plots, whereas $20 \%$ more seed yield, averaged across year, irrigation and varieties, was obtained when it was grown in fertilized than in non-fertilized plots (Table 2). Also, "Amorgos” (averaged across year and fertilization) produced $16 \%$ and $6 \%$ greater seed yield than "Serifos" and "Andros". Furthermore, the three chickpea varieties produced more seed yield in year 2 than in year 1 , which was higher under any irrigated and fertilization regime (Table 4). "Amorgos", "Serifos" and "Andros" (averaged across year and fertilization) produced $30 \%$, 31\%, and 33\% more seed yield under irrigated than under non-irrigated plots, 
Table 4. Seed yield of three chickpea varieties as affected by irrigation and nitrogen fertilization during 2007/ 08 (year 1) and 2008/09 (year 2).

\begin{tabular}{|c|c|c|c|c|c|c|c|c|}
\hline \multirow[t]{4}{*}{ Chickpea variety } & \multicolumn{8}{|c|}{ Irrigation (mm) } \\
\hline & \multicolumn{4}{|c|}{0} & \multicolumn{4}{|c|}{60} \\
\hline & \multicolumn{8}{|c|}{ Nitrogen fertilization $\left(\mathrm{kg} \mathrm{ha}^{-1}\right)$} \\
\hline & \multicolumn{2}{|c|}{$50^{1}$} & \multicolumn{2}{|c|}{$50+40^{2}$} & \multicolumn{2}{|c|}{50} & \multicolumn{2}{|c|}{$50+40$} \\
\hline Year 1 & \multicolumn{8}{|c|}{$\mathrm{tha}^{-1}$} \\
\hline Amorgos & 2.19 & $\mathrm{~h}$ & 3.13 & defgh & 3.73 & cderf & 4.90 & abc \\
\hline Serifos & 2.23 & gh & 2.30 & fgh & 3.19 & defgh & 3.70 & cdefg \\
\hline Andros & 2.28 & fgh & 2.56 & efgh & 3.44 & cdefgh & 4.03 & bcde \\
\hline \multicolumn{9}{|l|}{ Year 2} \\
\hline Amorgos & 3.31 & defgh & 3.90 & bcde & 3.58 & cdefgh & 5.61 & a \\
\hline Serifos & 2.60 & efgh & 3.51 & cdefgh & 3.50 & cdefgh & 4.58 & abcd \\
\hline Andros & 3.16 & defgh & 3.51 & cdefgh & 4.39 & abcd & 5.25 & $\mathrm{ab}$ \\
\hline $\mathrm{CV}, \%$ & \multicolumn{8}{|c|}{15.2} \\
\hline
\end{tabular}

Means with different letter indicate significant difference according to Tukey's Honestly Significant Difference test at $P=0.05$. ${ }^{1}$ Fertilization before crop planting. ${ }^{2}$ Fertilization at blossom growth stage.

whereas their respective seed yield (averaged across year and irrigation) was 27\%, 18\% and 13\% higher in fertilized as compared with non-fertilized plots. Finally, "Amorgos", "Serifos", "Andros", averaged over years and grown in fertilized plots, produced 22.5, $14 \%$ and $11 \%$ more seed yield, respectively, than in non-fertilized plots, whereas their respective increase in irrigated and fertilized plots was 30, 15.5\% and 15.5\% (Table 4).

\section{Discussion}

The recorded greater total dry biomass and seed yield of chickpea varieties grown in irrigated and fertilized plots than in non-irrigated and non-fertilized plots agree with results reported by Islam et al. [24] who found that application of $15 \mathrm{~kg} \cdot \mathrm{N} \cdot \mathrm{ha}^{-1}$ before crop planting and $15 \mathrm{~kg} \cdot \mathrm{N} \cdot \mathrm{ha}^{-1}$ applied with irrigation at flower initiation growth stage increased chickpea yield by $51 \%$ as compared with that obtained in non-fertilized and non-irrigated plots. Also, Bakhsh et al. [25] found 36\% increase in total dry weight due to irrigation. The chickpea dry biomass reduction in non-irrigated plots could be attributed to lower $\mathrm{CO}_{2}$ accumulation in biochemical reactions of photosynthesis and therefore to lower carbohydrates production [26] [27].

The significantly greater seed yield of chickpea grown in year 2 could be mainly attributed to higher and more uniformly distributed rainfall and temperature prevailing during November 2008 to May 2009, as compared with the respective rainfall and temperature in year 1 (Figure 1).

The increased chickpea seed yield by $30.5 \%$ and $20 \%$ in irrigated and fertilized plots, respectively, as compared with that in non-irrigated and non-fertilized plots, is in agreement with the results reported by Pawar et al. [28] who found that seed yield was increased with irrigation and the increase was not affected by the growth stage of chickpea at the irrigation time. Also, Bakhsh et al. [25] found that seed yield and most of their yield components were improved by $17 \%$ with irrigation, while Rabieyan et al. [29] reported that the effect of biofertilizer (biosuper) application on water deficit stress was lower than that of complete irrigation. In addition, the combined effect of nitrogen + biofertilizer application on water deficit stress was higher than that recorded after their separate applications. In general, the application of nitrogen + biofertilizer under complete irrigation regime increased seed weight, pod weight per plant and 1000-seed weight of chickpea [30]. Furthermore, the combination of inoculation, fertilization $\left(20 \mathrm{~kg} \cdot \mathrm{N} \cdot \mathrm{ha}^{-1}\right)$ and irrigation increased more seed yield of chickpea as compared with that grown under the combination of fertilization $\left(60 \mathrm{~kg} \cdot \mathrm{N} \cdot \mathrm{ha}^{-1}\right)$ and irrigation [31]. In addition, the nitrogen fertilization or the inoculation resulted in higher seed yield and protein ratio of chickpea grown under irrigated than under non-irrigated conditions. Also, Zaman and Malik [32] reported that maximum seed yield, dry matter, pods per plant, seeds per pod and 1000-seed weight of chickpea were obtained with two irrigations, 
while Ali et al. [33] found that the rate of fertilization had a significant effect on seed yield of chickpea but it was differentiated among genotypes. Finally, the lower seed yield of chickpea grown in non-irrigated and non-fertilized plots could be attributed to drought stress that reduces plant growth and yield by reducing leaf surface area and rate of photosynthesis [17]. On the contrast to our results, Mohamed [34] found that the application of 90 or $180 \mathrm{~kg} \cdot \mathrm{N} \cdot \mathrm{ha}^{-1}$ did not have any effect on seed yield and yield components of chickpea. The lack of irrigation or rainfall water to increase the efficient use of nitrogen applied could be the reason for these differences.

\section{Conclusion}

Although chickpea is considered one of the most tolerant food legumes to environmental stresses such as drought, high temperatures and poor soils, the results of this study indicate that the three chickpea varieties produce higher seed yield under irrigated and nitrogen fertilized conditions. These findings support strongly the evidence that the application of $90 \mathrm{~kg} \cdot \mathrm{N} \cdot \mathrm{ha}^{-1}\left(50 \mathrm{~kg} \cdot \mathrm{N} \cdot \mathrm{ha}^{-1}\right.$ before crop planting $+40 \mathrm{~kg} \cdot \mathrm{N} \cdot \mathrm{ha}^{-1}$ at blossom growth stage) in combination with irrigation $(30+30 \mathrm{~mm}$ of water) results in higher chickpea seed yield, which increases its profitability and makes this crop more important as food security crop for smallholder farmers in the semi-arid Mediterranean environments.

\section{References}

[1] FAO (2004) Production Yearbook 2003. Food and Agricultural Organization of the United Nations, Rome, Vol. 58.

[2] Ali, N. and Kumar, S. (2006) Pulse Production in India. Yojana, 13-15.

[3] Gupta, Y.P. (1988) Nutritive Value of Pulses. In: Rawanujam, B.S. and Jain, H.K., Eds., Pulse Crop, Oxford IBH Publishing Co. Pvt. Ltd., New Delhi, 561-601.

[4] Siddique, K.H.M., Brinsmead, R.B., Knight, R., Knights, E.J., Paull, J.G. and Rose, I.A. (2000) Adaptation of Chickpea (Cicer arietinum L.) and Faba Bean (Vicia faba L.) to Australia. In: Knight, R., Ed., Cool-Season Food Legumes, Kluwer, Adelaide, 289-303.

[5] Singh, K.B. (1997) Chickpea (Cicer arietinum L.). Field Crops Research, 53, 161-170. http://dx.doi.org/10.1016/S0378-4290(97)00029-4

[6] Singh, N., Kaur, M. and Sandhu, K.S. (2005) Physicochemical and Functional Properties of Freeze-Dried and oven Dried Corn Gluten Meals. Drying Technology, 23, 1-14. http://dx.doi.org/10.1081/DRT-200054253

[7] Kader, M.A. (2002) Effects of Azotobacter inoculants on the Yield and Nitrogen Uptake by Wheat. Journal of Biological Science, 2, 259-261. http://dx.doi.org/10.3923/jbs.2002.259.261

[8] Nishita, G. and Joshi, N.C. (2010) Growth and Yield Response of Chickpea (Cicer arietinum L.) to Seed Inoculation with Rhizobium sp. Nature Science, 8, 232-236.

[9] BARC (Bangladesh Agricultural Research Council) (1997) Fertilizer Recommendation Guide, Farmgate, Dhaka, 69.

[10] Chaudhari, R.K., Patel, T.D., Patel, J.B. and Patel, R.H. (1998) Response of Chickpea Cultivars to Irrigation, Nitrogen and Phosphorus On Sandy Clay Loam Soil. International Chickpea Newsletter, 5, 24-26.

[11] Gupta, N. and Singh, R.S. (1982) Effect of Nitrogen, Phosphorus and Sulphur Nutrition on Protein and Amino Acids in Chickpea (Cicer arietinum L.). Indian Journal of Agricultural Research, 16, 113-117.

[12] Khan, H., Haqqani, A.M., Khan, M.A. and Malik, B.A. (1992) Biological and Chemical Fertilizer Studies in Chickpea Grown under Arid Conditions of Thal (Pakistan). Sarhad Journal of Agriculture, 8, 321-327.

[13] Jain, L.K. and Singh, P. (2003) Growth and Nutrient Uptake of Chickpea as Influenced by Phosphorus and Nitrogen. Crop Research, 25, 401-413.

[14] Siddique, K.H.M., Loss, S.P., Regan, K.L. and Jettner, R.L. (1999) Adaptation and Seed Yield of Cool Season Grain Legumes in Mediterranean Environments of South-Western Australia. Australian Journal of Agricultural Research, 50, 375-387. http://dx.doi.org/10.1071/A98096

[15] Thangwana, N.M. and Ogola, J.B.O. (2012) Yield and Yield Components of Chickpea (Cicer arietinum): Response to Genotype and Planting Density in Summer and Winter Sowings. Journal of Food, Agriculture \& Environment, 10, 710-715.

[16] Singh, K.B. (1993) Problems and Prospects of Stress Resistance Breeding in Chickpea. In: Sing, K.B. and Saxena, M.C., Eds., Breeding for Stress Tolerance in Cool-Seasons Food Legumes, Wiley, Chichester, 17-35.

[17] Krishnamurthy, L., Kashiwagi, J. and Vpadhayaya, M.D. (2003) Genetic Diversity of Drought Avoidance Root Traits in the Mini-Core Germplasm Collection of Chickpea. International Chickpea and Pigeon Pea News Letters, 10, 21-29. 
[18] Leport, L., Turner, N.C., Davies, S.L. and Siddique, K.H.M. (2006) Variation in Pod Production and Abortion among Chickpea Cultivars under Terminal Drought. European Journal of Agronomy, 24, 236-246. http://dx.doi.org/10.1016/j.eja.2005.08.005

[19] Saraf, C.S., Baldev, B., Ali, M. and Slim, S.N. (1990) Improved Cropping Systems and Alternative Cropping Practices, In: Chickpea in the Nineties: Proceedings of the 2nd Inter Workshop on Chickpea Improvement, ICRISAT Center, India, Patancheru, 502-524.

[20] Rajala, A., Hakala, K., Makela, P., Muurinen, S. and Peltonen-Sainio, P. (2009) Spring Wheat Response to Timing of Water Deficit through Sink and Grain Filling Capacity. Field Crops Research, 114, 263-271. http://dx.doi.org/10.1016/j.fcr.2009.08.007

[21] Saccardo, F., Crinò, P. and Giordano, I. (2001) Cece (Cicer arietinum L.). In: Leguminose e agricoltura sostenibile, Edagricole, Bologna, 555-590.

[22] Statistical Package for the Social Sciences (SPSS) (1998) SPSS Base 8.0 User’s Guide and SPSS Applications Guide. SPSS, Chicago.

[23] MSTAT-C (1988) MSTAT-C, a Microcomputer Program for the Design, Arrangement, and Analysis of Agronomic Research. Michigan State University East Lansing, East Lansing.

[24] Islam, M.S., Kawochar, M.A., Karim, M.F., Ali, M.H. and Islam, M.K. (2010) Response of Chickpea to Integrated Nitrogen and Irrigation Management. Journal of Experimental Biosciences, 1, 41-45.

[25] Bakhsh, A., Malik, S.R., Aslam, M., Iqbal, U. and Haqqani, A.M. (2007) Response of Chickpea Genotypes to Irrigated and Rain-Fed Conditions. International Journal of Agriculture \& Biology, 9, 590-593.

[26] Hopkins, W.G. and Hüner, N.P. (2004) Introduction to Plant Physiology. 3rd Edition, John Wiley \& Sons, Inc, Hoboken.

[27] Potts, D.L., Stanley Harpole, W., Goulden, M.L. and Suding, K.N. (2008) The Impact of Invasion and Subsequent Removal of an Exotic Thistle, Cynara cardunculus, on $\mathrm{CO}_{2}$ and $\mathrm{H}_{2} \mathrm{O}$ Vapor Exchange in a Coastal California Grassland. Biological Invasions, 10, 1073-1084. http://dx.doi.org/10.1007/s10530-007-9185-y

[28] Pawar, H.K., Khade, K.K. and More, V.D. (1992) Studies on Crop Sequences under Irrigation Constrain. Journal of Maharashtra Agricultural Universities, 17, 299-301.

[29] Rabieyan, Z., Yarnia, M. and Kazemi-e-Arbat, H. (2011) Effects of Biofertilizers on Yield and Yield Components of Chickpea (Cicer arietinum L.) under Different Irrigation Levels. Australian Journal of Basic and Applied Sciences, 5, 3139-3145.

[30] Rabieyan, Z. and Kashani, Z.F. (2012) The Effect of Irrigation and Biofertilizer on Seed and Yield Index on Two Chickpea (Cicer arietinum L.) Varittes. Advances in Environmental Biology, 6, 1528-1533.

[31] Yagmur, M. and Kaydan, D. (2011) Plant Growth and Protein Ratio of Spring Sown Chickpea with Various Combinations of Rhizobium Inoculation, Nitrogen Fertilizer and Irrigation under Rain Fed Condition. African Journal of Agricultural Research, 6, 2648-2654.

[32] Zaman, A. and Malik, S. (1988). Effect of Irrigations Levels and Mulches on Yield Attributes and Yield of Green Gram in Laterite Soil. Environmental Ecology, 6, 437-440.

[33] Ali, A., Ali, Z., Iqbal, J., Nadeem, M.A., Akhtar, N., Akra, H.M. and Sattar, A. (2010) Impact of Nitrogen and Phosphorus on Seed Yield of Chickpea. Journal of Agricultural Research, 48, 335-343.

[34] Mohamed, A.K. (1990) Effect of Planting Method, Irrigation and Nitrogen Fertilizer Application on Grain Yield and Yield Components of Chickpea (Cicer arietinum) in Shendi Area, Sudan. Acta Agronomica Hungarica, 39, 393-399. 